\title{
Effects of Growth Retardation and Asphyxia on Brain Electrolytes and on Glycolysis in Developing Rats
}

\author{
B. P. F. ADLARD ${ }^{1261}$, S. W. DE SOUZA, AND JOHN DOBBING \\ Department of Child Health, University of Manchester, Manchester, United Kingdom
}

\begin{abstract}
Extract
During postnatal brain development in the rat there is a progressive decrease in the $\mathrm{Na}^{+} / \mathrm{K}^{+}$ratio, which correlated with increasing activity of $\mathrm{Na}^{+}-\mathrm{K}+$-activated ATPase. Undernutrition during intrauterine and early postnatal development (4-6 days) did not alter the $\mathrm{Na}^{+} / \mathrm{K}+$ ratio, although there was a deficit in brain weight. However, undernutrition during the suckling period retarded the progressive fall in $\mathrm{Na}+/ \mathrm{K}+$ ratio and rise in ATPase activity. The altered $\mathrm{Na}+/ \mathrm{K}^{+}$ratio in these animals did not appear to be caused by change in brain carbohydrate metabolism.

Developing rats undernourished until 4-6 days resembled the intrauterine growthretarded human baby as regards deficits in body weight, relative sparing of the brain compared with other organs, and depleted carbohydrate reserves.

The undernourished 4-6-day-old rat tolerated asphyxia as well as the well nourished rat of the same age. After asphyxia, the $\mathrm{Na}+/ \mathrm{K}+$ ratio reverted to unity and there was an increase in brain water. Liver carbohydrate reserves did not appear to be a limiting factor that determined the point of death.
\end{abstract}

\section{Speculation}

The normal gradients of $\mathrm{Na}+$ and $\mathrm{K}+$ between the cell and its environment in developing rat brain may be altered by asphyxia or undernutrition as a result of a defect in the $\mathrm{Na}^{+}$pump mechanism. Such a defect may be caused by asphyxia at a time in rat brain development equivalent to that of the human brain in the perinatal period, i.e., in the first stages of the brain growth spurt. Undernutrition, however, may retard development of the $\mathrm{Na}+$ pump only when its time of application includes the period of most rapid brain growth and maturation.

\section{Introduction}

The developing brain shows a fall, followed by a progressive accumulation of $\mathrm{K}+$ and loss of $\mathrm{Na}+$ with age. In the rat these changes are completed by the 4th week of postnatal life [7]. In the postnatal period, these changes are correlated with increasing activity of $\mathrm{Na}+\mathrm{K}+$-activated ATPase (ATP phosphohydrolase EC. 3.6.1.3.) and probably reflect an increasingly efficient $\mathrm{Na}+$ pump $[1,18]$.

It is possible that the efficiency of the brain $\mathrm{Na}+$ 
pump may be altered by either undernutrition or anoxia. In infants with protein-calorie malnutrition, behavior disorders are said to be associated with a deficit in brain $\mathrm{K}+[10]$. Also, the normal brain water and electrolyte composition is altered by prolonged asphyxia and acute anoxia [6, 17] and by an anoxic-ischemic insult [20].

These findings have led to the present study which examines the combined and separate effects of growth retardation and asphyxia on cerebral electrolytes in the postnatal rat. In addition, the activity of brain ATPase and rate of cerebral glycolysis have been studied in undernourished and normal animals.

\section{Methods}

\section{Animals}

Rats of a black and white hooded strain were used. The day of mating was determined by examination of vaginal lavages for sperm. Litters were reduced to eight animals at birth.

\section{Diet}

Undernutrition was achieved by giving mothers a restricted quantity of food [24] either from conception (offspring killed 27 days after conception; i.e., 4-6 days after birth) or from the 7th day of gestation (offspring killed 21 or 25 days after birth). Undernourished mothers were fed $10 \mathrm{~g} / 24 \mathrm{hr}$ during pregnancy, 15 $\mathrm{g} / 24 \mathrm{hr}$ during the 1st week after delivery, $20 \mathrm{~g} / 24 \mathrm{hr}$ during the 2 nd week, and $25 \mathrm{~g} / 24 \mathrm{hr}$ thereafter. This represents about $50 \%$ of the ad libitum intake at this time. Control mothers had unlimited access to the same diet and all animals received water ad libitum.

\section{Asphyxia Procedure}

Rats were anesthetized with urethane $(0.5 \mathrm{mg} / \mathrm{g}$, body wt, i.p.) and were either returned to the mother (controls) or were asphyxiated. Rats were subjected to prolonged asphyxia to death in groups of four in an airtight $500-\mathrm{ml}$ jar suspended in a water bath at $37^{\circ}$. Survival time was defined as the interval between being placed in the jar and the occurrence of the last gasp.

Control rats were decapitated. Brain from asphyxiated and control rats was removed immediately after death and divided sagittally. One-half was used for electrolyte and the other for water estimation.

\section{Water Estimation}

Brain tissue was dried in an oven to constant weight at $100^{\circ}$. The loss of weight due to loss of water [14] was expressed as a percentage of wet weight.

\section{Electrolyte Estimation}

$\mathrm{Na}+$ and $\mathrm{K}+$ were determined by flame photometry after digestion of brain tissue in concentrated nitric acid [14].

\section{Total Carbohydrate}

Carbohydrate content of liver or heart was determined according to the method of Kemp and van Heijningen [12] with glucose as a standard. This method estimates glycogen and glucose combined and is uninfluenced by postmortem changes in the few minutes required for processing the tissue.

\section{ATPase Activity}

ATPase was determined according to the method of Swanson et al. [21] in the presence of $100 \mathrm{mM} \mathrm{Na}+, 30$ $\mathrm{mM} \mathrm{K}+$, and $3 \mathrm{mM} \mathrm{Mg}^{2+}$ using a $2.5 \%(\mathrm{w} / \mathrm{v})$ homogenate prepared in ice-cold $0.32 \mathrm{M}$ sucrose.

\section{Glycolysis Experiments}

The rate of lactate formation from glucose or glucose 6-phosphate was determined according to the method of Lea and Walker [13] using a 10\% (w/v) homogenate prepared in ice-cold $0.32 \mathrm{M}$ sucrose- $1 \mathrm{mM}$ ethylenediaminetetraacetic acid $(\mathrm{pH}$ 7.4). ATP (1.0 $\mathrm{mM}$ ) and nicotinamide adenine dinucleotide (1.0 HIM) were included in the incubation medium and lactate was estimated using lactate dehydrogenase [25].

\section{Results}

Undernutrition to 27 days after conception (4-6 days after birth)

Undernourished rats had deficits in body weight, brain weight, liver weight, and heart weight (Table I). The percentage deficit in brain weight $(31 \%)$ was less when compared with liver (65\%), heart (64\%), and whole body $(58 \%)$. In other words, deficits in heart and liver weights were similar. The brain to liver ratio was almost twice the value in undernourished compared with the value in control (well nourished) animals.

Brain $\mathrm{K}+$ concentration was significantly somewhat higher in undernourished compared with well nour- 
ished rats, but $\mathrm{Na}+$ concentration, $\mathrm{Na}+/ \mathrm{K}+$ ratio, and water were not significantly different.

Total liver carbohydrate was reduced to $15 \%$ of normal and liver carbohydrate concentration to $42 \%$ of normal in undernourished rats (Table II). Although the total cardiac carbohydrate was reduced to $56 \%$ of normal in the same undernourished rats, the cardiac carbohydrate concentration was increased by $52 \%$ (Table II).

\section{Effects of Asphyxia}

The response of brain electrolytes and water to prolonged asphyxia did not differ between well nourished and undernourished groups (Table II). Both showed significantly reduced $\mathrm{K}+$ concentration and increased $\mathrm{Na}+$ concentration, water content, and $\mathrm{Na}+/ \mathrm{K}+$ ratio.

There was a consistent increase in liver weight after prolonged asphyxia, presumably because of congestion with blood. It was therefore not valid to compare liver carbohydrate concentrations in asphyxiated and control animals. Total liver and cardiac carbohydrate

Table I. Body and organ weights of well nourished and undernourished rats at 27 days of conceptual age ${ }^{1}$

\begin{tabular}{lcccc} 
& Well nourished & \multicolumn{3}{c}{ Undernourish ed } \\
\hline Body wt, R & $13.1 \pm 0.8$ & $5.5 \pm 1.5$ & $(-58)$ \\
Brain wt, S & $0.553 \pm 0 . .051$ & $0.380 \pm 0.045$ & $(-31)$ \\
Liver wt. R & $0.414 \pm 0 . .042$ & $0.146 \pm 0 . .054$ & $(-65)$ \\
Heart wt,. g & $0.0924 \pm 0.0118$ & $0.0338 \pm 0.0144$ & $(-64)$ \\
\hline
\end{tabular}

\footnotetext{
${ }^{1}$ Results are given as the means $( \pm$ SD) for 14 well nourished animals (from four litters) or 11 undernourished animals (from three litters). Figures in parentheses indicate the percentage weight deficit in undernourished compared with well nourished rats.
}

were markedly reduced by asphyxia (Table II), the effect being most pronounced in undernourished rats. Indeed, the combined effects of undernutrition and asphyxia reduced total liver carbohydrate by $95 \%$ and total cardiac carbohydrate by $80 \%$.

\section{Survival Times during Asphyxia}

Well nourished animals subjected to prolonged asphyxia in groups of four died after a mean $( \pm \mathrm{SD})$ of $46 \pm 1$ min (4 litters), whereas undernourished rats survived for $134 \pm 54 \mathrm{~min}$ (3 litters). Since both groups consisted of similar numbers and were initially exposed to the same volume of oxygen in air this difference was probably related to the smaller oxygen requirement of the undernourished group. This seemed to be confirmed by the finding that survival time of single rats in pure nitrogen was not significantly different between the groups (controls 1,019 \pm $104 \mathrm{sec}$, undernourished $972 \pm 142 \mathrm{sec}$ ).

\section{Undernutrilion from 7 Days after Conception to 21 or 25 Days Postnatal Age}

Rats undernourished to 21 days of age had a deficit in body weight of $63 \%$, a deficit in brain weight of $19 \%$, and a deficit in forebrain weight of $18 \%$. Undernutrition tended to result in a reduced forebrain $\mathrm{K}+$ concentration and a corresponding elevation in $\mathrm{Na}+$ (Table III). These changes, although not individually significant, led to a higher $\mathrm{Na}+/ \mathrm{K}+$ ratio in undernourished compared with well nourished animals. Forebrain ATPase activity showed a $14 \%$ deficit in the undernourished group (Table III).

Rats undernourished to 25 days of age had a deficit in body weight of $68 \%$ and a deficit in brain weight of

Table II. Effect of asphyxia or undernutrition on brain electrolytes and water and on hepatic and cardiac total carbohydrate in rats of 27 days conceptual age ${ }^{1}$

\begin{tabular}{|c|c|c|c|c|}
\hline & \multicolumn{2}{|c|}{ Well nourished } & \multicolumn{2}{|c|}{ Undernourished } \\
\hline & Normal (14) & Asphyxiated (16) & Normal (11) & Asphyxiated (12) \\
\hline Brain $\mathrm{Na}^{+}$, jumoles/g & $66.64 \pm 3.33$ & $73.21 \pm 3.36^{2}$ & $69.95 \pm 4.28$ & $76.09 \pm 5.563$ \\
\hline Brain $\mathrm{K}^{+}, / \wedge$ moles $/ \mathrm{g}$ & $79.36 \pm 2.36$ & $75.16 \pm 2 . \mathrm{O3}^{2}$ & $82.46 \pm 3.58^{4}$ & $76.01 \pm 2.73^{2}$ \\
\hline Brain $\mathrm{Na}+/ \mathrm{K}^{+}$ratio & $0.871 \pm 0.039$ & $0.975 \pm 0.053^{2}$ & $0.849 \pm 0.052$ & $1.001 \pm 0.062^{2}$ \\
\hline Brain water, $\%$ wet wt & $88.12 \pm 0.21$ & $88.61 \pm 0.84^{5}$ & $87.97 \pm 0.21$ & $88.47 \pm 0.20^{2}$ \\
\hline Hepatic carbohydrate, $\mathrm{mg} /$ liver & $6.87 \pm 2.06$ & $3.67 \pm 1.81^{2}$ & $1.03 \pm 0.82^{6}$ & $0.37 \pm 0.19^{5}$ \\
\hline Cardiac carbohydrate, /zg/heart & $350 \pm 161$ & $146 \pm 56^{2}$ & $195 \pm 72^{6}$ & $71 \pm 48^{s}$ \\
\hline
\end{tabular}

\footnotetext{
${ }^{1}$ Results are given as means $( \pm \mathrm{SD})$ of the number of animals (indicated in parentheses).

${ }^{2} P<0.001$ (normal versus asphyxiated).

${ }^{3} P<0.01$ (normal versus asphyxiated).

${ }^{4} P<0.05$ (well nourished normal versus undernourished normal).

${ }^{6} P<0.05$ (normal versus asphyxiated).

${ }^{6} P<0.001$ (well nourished normal versus undernourished normal).
} 
Table III. Effect of undernutrition on forebrain electrolytes, water, and ATPase activity in 21-day-old rats ${ }^{1}$

\begin{tabular}{|c|c|c|c|}
\hline & Well nourished & Undernourished & $P$ value \\
\hline Body wt, g & $\begin{array}{c}46.5 \mathrm{db} 5.3 \\
(20)\end{array}$ & $\begin{array}{c}17.1 \mathrm{~d}=3.0 \\
(20)\end{array}$ & $<0.001$ \\
\hline Brain wt, $\mathrm{g}$ & $\begin{array}{c}1.440 \pm 0.028 \\
(20)\end{array}$ & $\begin{array}{c}1.171 \underset{(20)}{ \pm} 0.104 \\
\underset{(20)}{ }\end{array}$ & $<0.001$ \\
\hline $\begin{array}{l}\text { Forebrain Na+, } \\
\quad \text { /imoles/g }\end{array}$ & $53.83 \underset{(10)}{d=2.72}$ & $\begin{array}{c}55.40=\mathrm{b} 2.36 \\
(10)\end{array}$ & n.s. \\
\hline$\underset{\wedge_{\text {moles } / g}^{\text {Forebrain }}}{\mathrm{K}^{+},}$ & $90.91 \underset{(10)}{ \pm} 2.90$ & $\begin{array}{c}89.58 \mathrm{~d}=2.79 \\
(10)\end{array}$ & n.s. \\
\hline $\begin{array}{l}\text { Forebrain } \mathrm{Na}+/ \mathrm{K}+ \\
\text { ratio }\end{array}$ & $\begin{array}{c}0.592 \pm 0.024 \\
(10)\end{array}$ & $\begin{array}{c}0.619 \underset{(10)}{ \pm} 0.028 \\
(10)\end{array}$ & $<0.05$ \\
\hline $\begin{array}{l}\text { Forebrain water, \% } \\
\text { wet wt }\end{array}$ & $\begin{array}{c}81.72 \pm 0.23 \\
(10)\end{array}$ & $\begin{array}{c}82.59 \pm 0.51 \\
(10)\end{array}$ & $<0.001$ \\
\hline $\begin{array}{l}\text { Forebrain ATPase } \\
\text { activity, jumole } / \mathrm{g} / \mathrm{hr}\end{array}$ & $\begin{array}{c}2299 \mathrm{db} 126 \\
(10)\end{array}$ & $\begin{array}{c}1984 \mathrm{~d}=126 \\
(10)\end{array}$ & $<0.001$ \\
\hline
\end{tabular}

${ }^{1}$ Results are given as means $(\mathrm{d}=\mathrm{SD})$ of the number of animals (indicated in parentheses). In all 40 rats (equal numbers of each sex) from 10 litters (5 well nourished, 5 undernourished) were used. ATPase activity is expressed as micromoles of inorganic phosphorus formed per gram of tissue, wet wt, per hour, n.s.: Not significant.

Table IV. Rates of glycolysis by homogenates of forebrain from well nourished and undernourished 25-day-old rats ${ }^{1}$

\begin{tabular}{lccc}
\hline & Well nourished & Undernourished & $P$ value \\
\hline Body wt, g & $\begin{array}{c}60.0 \pm 8.2 \\
(14)\end{array}$ & $\begin{array}{c}19.2 \pm 2.4 \\
(14)\end{array}$ & $<0.001$ \\
Brain wt, g & $1.432 \pm 0.048$ & $1.083 \mathrm{db} 0.039$ & $<0.001$ \\
& $(14)$ & $(14)$ & \\
$\begin{array}{l}\text { Lactate formation from } \\
\text { glucose, /imole/g/hr }\end{array}$ & $170 \pm 12$ & $177 \pm 18$ & n.s. \\
$\begin{array}{l}\text { Lactate formation from } \\
\text { glucose 6-phosphate, } \\
\text { /tmole/g/hr }\end{array}$ & $\begin{array}{c}(8) \\
(14)\end{array}$ & $453 \pm 26$ & $<0.05$ \\
\hline
\end{tabular}

\footnotetext{
${ }^{1}$ Results are given as means (rfe SD) for the number of animals (indicated in parentheses). In all 28 rats equal numbers of each sex from 13 litters were used. Rate of lactate formation is expressed as micromoles of lactate per gram of tissue, wet wt, per hour. n.s.: Not significant.
}

$24 \%$. The optimal rate of brain glycolysis (lactate formation from glucose in vitro) was not affected by undernutrition (Table IV), although there was a significant $5 \%$ reduction in the rate of lactate formation from glucose 6-phosphate.

\section{Discussion}

The brain of the 4-6-day-old rat is in a similar phase of development to that of the human brain in the perinatal period, in that the brain weight and total numbers of brain cells have reached approximately the same proportion of their adult achievement $(8,9)$. In its response to undernutrition, the 4-6-day-old rat resembled the intrauterine growth-retarded baby as regards deficits in body weight, relative sparing of the brain compared with other organs [11], and depleted carbohydrate reserves [19].
In undernourished 4-6-day-old rats the brain $\mathrm{Na}+/ \mathrm{K}+$ ratio was similar to that for controls. This ratio is probably a good index of cationic membrane gradients which are maintained by the $\mathrm{Na}+$ pump. Since $\mathrm{Na}+/ \mathrm{K}+$ ratio is only a little less than unity in the 1st week of life [7], Na+ pump activity is very low and appears not be to altered by undernutrition during prenatal and early postnatal life.

Rats continuously undernourished from 7 days of conceptual age until the end of the suckling period, however, showed an elevation in brain water and $\mathrm{Na}+/ \mathrm{K}+$ ratio compared with well nourished control. The progressive fall with age in the sodium to potassium ratio may have been retarded by undernutrition. Similar findings reported in hypothyroid rats may be due to retarded development of brain ATPase [23]. In undernourished rats there may be a similar mechanism for the altered electrolyte balance since brain ATPase activity was reduced by undernutrition.

Alternatively, changes in the proportion of $\mathrm{Na}+$ and $\mathrm{K}+$ could result from a deficit in brain carbohydrate metabolism as has been proposed for muscle tissue of malnourished children $[3,15,16]$. This seems to be unlikely in the case of brain since glycolytic rate in -vitro (lactate production from glucose) was not affected by growth retardation. Furthermore, it has been shown [22] that undernutrition from birth to 9 days of age in the rat does not affect brain concentrations of ATP, phosphocreatine, or glucose.

The deficit in forebrain ATPase activity in rats undernourished during the suckling period was of the same order as that of acetylcholinesterase [2]. Inasmuch as these enzymes have a similar subcellular distribution in rat brain, showing high activity in synaptosomes and microsomes [1], these particles may be particularly affected by nutrition in the suckling period. Forebrain water content was also higher in the undernourished group (Table III); this is the usual finding in developing brains subjected to growth retardation, and is presumably due to relative developmental immaturity at an age when normal water content is still falling.

Undernourished compared with well nourished 4-6-day-old rats survived longer during prolonged asphyxia but for similar periods in nitrogen. These differences could be related to metabolic rates, oxygen requirements, and cardiac glycogen [5]. It might be expected that the deficit in liver carbohydrate and the high brain weight to liver weight ratio in undernour- 
ished animals would reduce the survival time. However, there were still considerable reserves of liver carbohydrate in all of the asphyxiated animals after death. Therefore liver carbohydrate could not have been a limiting factor in determining the point of death.

The changes in brain water and electrolytes in undernourished and well nourished animals asphyxiated to death were similar. There was an increase in brain water and in the $\mathrm{Na}+/ \mathrm{K}+$ ratio. The $\mathrm{Na}+/ \mathrm{K}+$ ratio reverted to unity, probably reflecting complete failure of the Na+ pump because of lack of ATP. The increase in brain water may be due to water accumulating in glial cells from damaged blood vessels [4]. These changes, therefore, suggest a form of tissue metabolic damage that could have resulted from anoxia and ischemia.

\section{Summary}

Undernutrition during prenatal and early postnatal life (4-6 days) in the rat did not alter the $\mathrm{Na}+/ \mathrm{K}+$ ratio in the brain. However, undernutrition in the suckling period retarded the progressive fall in the brain $\mathrm{Na}+/ \mathrm{K}+$ ratio and increase in ATPase activity, but did not alter the rate of brain glucose metabolism.

In the undernourished rat, there was a deficit in body weight and a relative sparing of the brain compared with other organs. Total liver and cardiac carbohydrate reserves and liver carbohydrate concentration were reduced, but the cardiac carbohydrate concentration was greater compared with controls.

Undernourished 4-6-day-old rats tolerated asphyxia as well as well-nourished controls, at least in terms of survival time. Changes in brain $\mathrm{Na}+/ \mathrm{K}+$ ratio and water were similar and liver carbohydrate reserves did not appear to be a limiting factor in determining the point of death.

\section{References and Notes}

1. ABDEl-Latif, A. A., SMITH, J. P., AND ELlington, E. P.: Subcellular distribution of sodium-potassium adenosine triphosphatase, acetylcholine and acetylcholinesterase in developing brain. Brain Res., 18: 441 (1970).

2. ADLARD, B. P. F., AND DOBBING, J.: Vulnerability of developing brain. V. Effects of fetal and postnatal undernutrition on regional brain enzyme activities in 3 week old rats. Pediat. Res., 6: 38 (1972).

3. ALLEYNE, G. A. O., FLORES, H., TRUST, P. M., AND WATERLOW,
J. C: Further studies on carbohydrate metabolism in infantile malnutrition. J. Physiol. (London), 213: 31P (1971).

4. BAKAY, L., AND LEE, J. C: The effect of acute hypoxia and hypercapnia on the ultrastructure of the central nervous system. Brain, Pi: 697 (1968).

5. DAWES, G. S., MOTT, J. C, AND SHELLEY, H. J.: The importance of cardiac glycogen for the maintenance of life in foetal lambs and newborn animals during anoxia. J. Physiol. (London), 146: 516(1959).

6. DE SOUZA, S. W.: Cerebral oedema induced by anoxia in newbom rats. Arch. Dis. Childhood, 46: 131 (1971).

7. DE SOUZA, S. W., AND DOBBING, J.: Cerebral edema in developing brain. I. Normal water and cation content in developing rat brain and post mortem changes. Exp. Neurol., 32: 431 (1971).

8. DOBBING, J.: Vulnerable periods in developing brain. In: A. N. Davison and J. Dobbing: Applied Neurochemistry, p. 287. (Blackwell Scientific Publications, Oxford, 1968).

9. DOBBING, J.: Undernutrition and the developing brain. Amer. J. Dis. Childhood, 120: 411 (1970).

10. GARROW, J. S.: LOSS of brain potassium in kwashiorkor. Lancet, ii: 643 (1967).

11. GRUENWALD, P.: Chronic fetal distress and placental insufficiency. Biol. Neonate, 5: 215 (1963).

12. KEMP, A., AND VAN HEIJNINGEN, A. J. M. K.: A colourimetric micro-method for determination of glycogen in tissues. Biochem. J., 56: 646 (1954).

13. LEA, M. A., AND WALKER, D. G.: Factors affecting hepatic glycolysis and some changes that occur during development. Biochem. J., 94: 655 (1965).

14. MCILWAIN, H., AND RODNIGHT, R.: Practical Neurochemistry, p. 20. Q. \& A. Churchill, Ltd., London, 1962).

15. METCOFF, J.: Biochemical effects of protein-calorie malnutrition in man. Ann. Rev. Med., 18: 377 (1967).

16. METCOFF, J., FRENK, S., YOSHIDA, T., PINEDO, R. T., KAISER, E., AND HANSON, J. D. L.: Cell composition and metabolism in Kwashiorkor (severe protein-calorie malnutrition in children). Medicine, 45: 365 (1966).

17. MEYER, J. S., GOTOH, F., EBIHARA, S., AND TOMITA, M.: Effects of anoxia on cerebral metabolism and electrolytes in man. Neurology, 15: 892 (1965).

18. SAMSON, F. E., AND QUINN, D. J.: $\mathrm{Na}^{+}-\mathrm{K}+$-Activated ATPase in rat brain development. J. Neurochem., 14: 421 (1967).

19. SHELLEY, J. J.: Carbohydrate reserves in the newborn infant. Brit. Med. J., 2:273 (1964).

20. SPECTOR, R. G.: Water content of the brain in anoxicischaemic encephalopathy in adult rats. Brit. J. Exp. Pathol., 42: 623 (1961).

21. SWANSON, P. D., BRADFORD, H. F., AND MCILWAIN, H.: Stimulation and solubilization of sodium ion-activated adenosine triphosphatase of cerebral microsomes by surface-active agents, especially polyoxyethylene ethers: actions of phospholipases and a neuroaminidase. Biochem. J., 92: 235 (1964).

22. THURSTON, J. H., PRENSKY, A. L., WARREN, S. K., AND ALBONE, K. R.: The effects of undernutrition upon the energy reserve of the brain and upon other selected metabolic intermediates in brains and livers of infant rats. J. Neurochem., 18: 161 (1971).

23. VALCANA, P., AND TIMIRAS, P. S.: Effect of hypothyroidism on 
ionic metabolism and $\mathrm{Na}^{+}-\mathrm{K}^{+}$-activated ATP phosphohydrolase in the developing rat brain. J. Neurochem., 16: 935 (1969).

24. Breeding Diet for Rats and Mice, Oxoid, Ltd., London, United Kingdom.

25. Assay kit, Boehringer Mannheim Corporation, Ealing, London, United Kingdom.

26. We wish to thank Professor J. A. Davis for helpful advice and criticism.
27. This research was supported by Medical Research Council, National Fund for Research into Crippling Diseases, and Special Donations Fund, Department of Child Health, University of Manchester.

28. Requests for reprints should be addressed to: B. P. F. ADLARD, PhJD., Department of Child Health, University of Manchester, Clinical Sciences Building, York Place, Manchester MIS OJJ, United Kingdom.

29. Accepted for publication December 19, 1972. 